\section{Correlation between interalar width and intercommissural width against mesiodistal width of central upper incisor in buginese tribe}

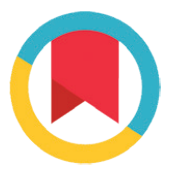

CrossMark

\author{
Bahruddin Thalib, ${ }^{*}$ Ayu Saputri
}

\title{
Abstract
}

Objective: Various types of anatomical landmarks of the face should match its proportions with the size of the teeth which are the interalar width, intercommissural width, interpupillary width, Intercanthal width and bizygomatic width. The objective of this study was to evaluate the correlation between interalar width and intercommissural width against mesiodistal incisivus centralis width in a group of Buginese tribe.

Material and Methods: Ninety nine Buginese tribe subjects aged $17-25$ were selected. The interalar width, intercommissural width and mesiodistal incisor centralis teeth were measured using caliper about three times for accuracy and precision.

Results: Mean of interalar width and mesiodistal incisor centralis maxilla width in males was more wider than females $(p<0.05)$, and intercommissural width in females was more wider than males $(p>0.05)$. The degree of correlation between interalar width against mesiodistal incisor centralis maxilla width was $0.030,-0.246$ and 0.225 in Buginese tribe, males and females $(p>0.05)$. The degree of correlation between intercommissural width against mesiodistal incisor centralis maxilla width in Buginese tribe was 0.054, 0.013 and 0.153 in Buginese tribe, males and females ( $p>0.05)$. The degree of correlation between interalar width and intercommissural width was 0.301 and 0.356 in Buginese tribe and males $(p<0.05)$ and 0.281 in females $(p>0.05)$.

Conclusion: Interalar width and intercommissural width was directly proportional to mesiodistal incisor centralis maxilla in a group of Buginese tribe. Interalar width and intercommissural width was inversely proportional to mesiodistal incisor centralis maxilla in males and directly inversely in females.
Department of Prosthodontic, Faculty of Dentistry, Hasanuddin University, Makassar, Indonesia
"Correspondence to: Bahruddin Thalib, Department of Prosthodontic, Faculty of Dentistry, Hasanuddin University, Makassar, Indonesia bathalib64@yahoo.com

Received: 28 January 2016

Revised: 25 April 2016

Accepted: 26 April 2016

Available Online: 30 April 2016

Keywords: Interalar width, Intercommissural width, Mesiodistal incisivus centralis, Maxilla width, Buginese tribe

Cite This Article: Thalib B, Saputri A. 2016. Correlation between interalar width and intercommissural width against mesiodistal width of central upper incisor in buginese tribe. Journal of Dentomaxillofacial Science 1(1): 25-30. D0I: 10.15562/jdmfs.v1i1.20

\section{Introduction}

Teeth are one of the important parts in body. Tooth loss does not only affect the appearance of the face but also have an effect on a person's psychological state, so the missing teeth should be replaced by using the denture. Replacement of missing teeth with denture should really be noticed in terms of aesthetics, good shape and size as well as its current status. Because any one just started wearing the denture was hoping to have denture that resemble their original teeth. ${ }^{1}$

Determination of the size of the teeth in the making of complete denture is an important stage, because tooth size of each person varies according to the tribe's origin, age, gender and its region of residence. In general, people with a large body size also has big teeth and male's tooth size is larger than the female. The size of the anterior maxillary teeth must match its proportions with the size of the face and head in order to obtained the conformity harmonic, i.e., that can optimize facial appearance with dentolabial relationship. ${ }^{2,3}$

Various types of anatomical landmarks of the face should match its proportions with the size of the teeth which is the interalar width, intercommissural width, interpupillary width, Intercanthal width and bizygomatic width. Some of face landmarks can be used as a guide in the selection of anterior teeth in complete denture, especially if the pre-extraction record such as radiography image, extracted teeth, model study, the remaining teeth, face shape and the shape of the curved jaw has been lost. ${ }^{4,5}$

The differences of facial anatomy landmark are influenced by age, gender, area of residence as well as the origin of his tribe. The tribe or race is a classification of the nation based on physical traits, such as face shape, hair and skin color. The tribes who originally inhibit the South Sulawesi: Makassarese, Torajanese and Buginese. All of those three tribes have their own characteristics of anatomical landmark. ${ }^{6}$

Facial anatomy landmark of people is derived from the same tissue of anterior teeth in oral embryology stages, so the face anatomical landmarks are closely associated with the size of the anterior teeth. Anatomical landmarks of the face can be measured by an anthropometry measurement method.-9

From the results of anthropometry measurements, interalar width and intercommissural width 
measurement, we obtain comparison or gold ratio of subjects' anterior teeth. From gold ratio, we can obtain results of facial landmark that can be used as a guide in determining the size of the anterior teeth which has the greatest relationship with the size of anterior teeth posterior teeth. Therefore, researchers are interested to know the relationship of the interalar width and intercommissural width against mesiodistal width of upper central incisor especially in the Buginese.

\section{Material and Methods}

The type of research used was an analytical observational study with nonexperimental correlation. This research was conducted in district of Pammana, Wajo Regency which was implemented in April 2015. The population of this research was community named Pammana Sub-district, Wajo Regency. The number of samples in this research was determined based on slovin formula calculations resulted to 99 people. For measuring the interalar width, samples were instructed to inhale and exhale a deep breath and as soon as possible for three times and then relaxed and hold their breath and did not widen the nose during measurement. For the measurement of intercommissural width, samples were instructed to occlude their teeth normally and relax, the lips should not be open, while for the measurement of upper central incisor, samples were instructed to smile and exposed the upper central incisor especially incisal part. The interalar width was measured for three times for precision and accuracy aspect and then averaged and recorded.

\section{Results}

To prove the existence of a relationship between the interalar width and intercommissural width as the independent variables toward the mesiodistal width of upper central incisor as dependent variable we performed the independent $\mathrm{t}$-test analysis. Significance between the dependent variable and the independent variables could be seen on p-value

Table 1 Age distribution of study sample

\begin{tabular}{lcccc}
\hline Age category & Frequency & Percentage & $\begin{array}{c}\text { Cumulative } \\
\text { percentage }\end{array}$ \\
\hline Valid & $15-19$ years old & 70 & 70.7 & 70.7 \\
& $20-24$ years old & 23 & 23.2 & 93.9 \\
& $25-29$ years old & 6 & 6.1 & 100.0 \\
& & 99 & 100.0 & \\
\hline
\end{tabular}

the relationship was significant, while $\mathrm{p}$ was $>0.05$ then the relationship was not significant. To know the magnitude of the relationship between the independent variable between interalar width and intercommissural width towards the dependent variable and the mesiodistal width of upper central incisor in Buginese, an analysis using Pearson correlation test was performed. A great relationship between the dependent variable and independent variable could be seen on r-values in the table. If the value of $r$ is 0 to 0.25 then the relationship is weak, If the value is 0.26 to 50 then the relationship is moderate, then 0.51 up to 0.75 the relationship is strong and then up to $>0.75$ is very strong. The results are shown in the table bebw:

Table 1 the results of the average age of patients in the study sample within the ranges of 15-19 years old were 70 people $(70.7 \%), 20-24$ years old were 23 people (23.2\%) and 25-29 years old were 6 people $(6.1 \%)$.

The table above table 2 shows that the average width of interalar of male was $36.37 \pm 2.69 \mathrm{~mm}$ where it was significantly higher than women $34.85 \pm 2.36 \mathrm{~mm}(\mathrm{p}<0.05)$ while the average width of intercommissural were significantly similar in both sexes $(p>0.05)$. Since the mesiodistal width of upper central incisor on male was $6.62 \pm 0.69$ $\mathrm{mm}$ which was also significantly higher than women $6.33 \pm 0.69 \mathrm{~mm}(\mathrm{p}<0.05)$.

Based on table above table 3 we obtained the results that there was a great relationship between interalar width toward mesiodistal width of upper central incisor in Buginese tribe that was 0.769. The relationship in this range, $0.769>0.05$ clarified that the correlation between these two variables was not significant and has poor positive direction $(\mathrm{r}=0.030)$. The table also declared that the result in males was 0.081 . It means $0.081>0.05$ and showed that the correlation between the two variable was also weak and insignificant followed by negative direction $(\mathrm{r}=-0.246)$. As for the women was 0.124 , it means $0.124>0.05$ and thus the correlation between these two variables was also insignificant and weak but has correlation with the positive direction $(r=0.225)$.

Based on table 4 above we obtained the result that showed the relationship between intercommissural width and mesiodistal width of upper central incisor in Buginese tribe were 0.594. That was, $0594>0.05$ and thus the correlation between these two variables was not significant and had little correlation with the positive direction $(\mathrm{r}=0.054)$. Based on the table 4 it was also obtained that result in males was 0.928 . It means $0.928>0.05$ and thus the correlation between the two variable was also not significant and the relationship was weak with 
Table 2 Measurement comparison of each variable on male and female

\begin{tabular}{|c|c|c|c|c|}
\hline Variable & Male $(n=51)$ & $\begin{array}{c}\text { Female } \\
(n=48)\end{array}$ & P-value & Result \\
\hline Interalar width & $36.37 \pm 2.69$ & $34.85 \pm 2.36$ & 0.004 & Significant \\
\hline $\begin{array}{l}\text { Intercommissural } \\
\text { width }\end{array}$ & $44.96 \pm 3.86$ & $45.18 \pm 3.41$ & 0.758 & $\begin{array}{c}\text { Not } \\
\text { significant }\end{array}$ \\
\hline $\begin{array}{l}\text { Mesiodistal width of } \\
\text { upper central incisor }\end{array}$ & $6.62 \pm 0.69$ & $6.33 \pm 0.69$ & 0.037 & Significant \\
\hline
\end{tabular}

Table 3 Relationship between interalar width and mesiodistal width of upper central incisor

\begin{tabular}{lccc}
\hline & $\begin{array}{c}\text { Pearson } \\
\text { correlation }(\mathbf{r})\end{array}$ & P value & Result \\
\hline All $(\mathrm{n}=99)$ & 0.030 & 0.769 & Not significant \\
Male $(\mathrm{n}=51)$ & -0.246 & 0.081 & Not significant \\
Female $(\mathrm{n}=48)$ & 0.225 & 0.124 & Not significant \\
\hline
\end{tabular}

Table 4 Relationship between intercommissural width and mesiodistal width of upper central incisor

\begin{tabular}{lccc}
\hline & $\begin{array}{c}\text { Pearson } \\
\text { correlation }(\mathbf{r})\end{array}$ & P value & Result \\
\hline All $(\mathrm{n}=99)$ & 0.054 & 0.594 & Not significant \\
Male $(\mathrm{n}=51)$ & -0.013 & 0.928 & Not significant \\
Female $(\mathrm{n}=48)$ & 0.153 & 0.300 & Not significant \\
\hline
\end{tabular}

Table 5 The relationship between interalar width and intercommissural width

\begin{tabular}{lccc}
\hline & $\begin{array}{c}\text { Pearson correlation } \\
(\mathbf{r})\end{array}$ & $\boldsymbol{p}$ value & Result \\
\hline All $(\mathrm{n}=99)$ & 0.301 & 0.002 & Significant \\
Male $(\mathrm{n}=51)$ & 0.356 & 0.010 & Significant \\
Female $(\mathrm{n}=48)$ & 0.281 & 0.053 & Not significant \\
\hline
\end{tabular}

negative direction $(\mathrm{r}=-0.013)$. As for the women was 0.300 . That means $0.300>0.05$ and thus the correlation between these two variables was also insignificant and weak but also have little correlation with the positive direction $(\mathrm{r}=0.153)$

Based on table 5 we obtained results that there was a great relationship between interalar width against intercommissural width in Buginese tribe 0.002 . That was $0.002<0.05$ and thus the correlation between these two variables was significant and their relationship was moderate with positive direction $(\mathrm{r}=0.301)$. The table also clarified the obtained result in males was 0.010 . It means $0.010<0.05$ and thus the correlation between these two variables was also significant and their relationship is moderate with positive direction $(\mathrm{r}=-0.356)$. And result on women is 0.053 . It means $0.053>0.05$ and thus the correlation between these two variables was not significant and had little correlation to do with the positive direction $(\mathrm{r}=0.281)$.

\section{Discussion}

Aesthetic factor is one of the big things that must be considered in patients with prosthetic care. Dentures have important role in improving aesthetic factors in patients with total edentulous case. Selection and preparation of artificial teeth depend on various factors. ${ }^{20}$

When there is no pre-extraction record, selection of the size and shape of artificial teeth will be difficult. Landmark of facial anatomy and the oral cavity can be used as a guide in terms of the selection of artificial teeth. ${ }^{17,20}$

Landmarks of facial anatomy include interalar width, intercommissural width, bizygomatic width, intercanthal width and interpupillary width. There are various different methods listed on some literature in the selection of the size of artificial teeth and there is no method that can last for long time and are used universally. ${ }^{3,9,20}$

Landmark of facial anatomy for people in Indonesia such as physical characteristics, face shape, hair and skin color varied according their respective tribes. ${ }^{25}$ According to two layer theory, the tribes in Indonesia were originally derives from Mongoloid race and austromelanesoid which form the proto-Malay sub-race. The next is sub-race proto-Malay race with Mongoloid race and formed deutro-Malay race. One of descendant in this group was Bugis ${ }^{7,10}$ but according to Punagi et al. ${ }^{6}$ there is no meaningful differences between the measurements of the face between the Buginese tribe in deutro-Malay race and Torajanese tribe in proto-Malay race because both tribes are includedin one group called "Western Malayopolynesian". As for the Buginese tribe was chosen as the subjectof this research because the Bugis is one of the largest tribes who have inhabited the territory of South Sulawesi. ${ }^{25}$

The subject in this research is the Bugis people for three generations. The intent of choosing Bugis for three generations is because both their parents as well as grandparent are of Bugis origin. It is based on the first law of Mendel (the law of segregation) stating "two members of a pair of genes divides forming gametes, so that one part of the gametes carry one member of a pair of genes and the other carry another pair of gene". Generally, the intent of the first law of Mendel is first: genes have alternative forms that organize variations on the character of its derivatives. This is the concept of two kinds of recessive alleles i.e. alleles that are not always visible from the outside and dominant alleles that appear 
from the outside, the second each individual brings a pair of genes, one from the elder males and one from females and third If a pair of these genes is different alleles, dominant allele will always be visible from the outside. From this characteristic, the facial profile of a tribe can still express from the outside to the third generation. ${ }^{26,27}$

Facial anatomy landmark that is studied in this research is interalar width and intercommissural width because nose, mouth and teeth are develop from the same tissue during growth and development of dental and craniofacial which is derived from the facial processes. This study was conducted to determine the relationship between interalar width and intercommissural width against mesiodistal width of upper central incisor in Buginese tribe.

There were 99 subjects in this research. They were the society of Pammana community sub-district, Sengkang. The research sample was 51 males and 48 females. There were 70 people with average age of 15-19 years old, 23 people with the average of 20-24 years old and 6 people with the average of 25-29 years old.

Calipers instruments used in this study to measure interalar width which is the distance between the outermost points of the alae nasi or left and right nose wings in a relaxed state and not widened. The instrument used to measure intercommissural width was the distance between the two points (cheilion) on left and right corners of the lips as well as for measuring the mesiodistal width of left or right upper central incisor. Mesiodistal width of upper central incisor was measured from mesioincisal corner to distoincisal corner. All variables were measured three times and then averaged as aspects of accuracy and precision. ${ }^{9,16}$ Every time we measure the variables that exist in every subject: the instruments were first sterilized using cotton with alcohol.

The result of this study showed the average size of interalar width in males was significantly wider than in females. This is in line with the research conducted by Qamar et al. ${ }^{9}$ which states that the average size of interalar width in males is wider than in females. In addition the results of interalar width measurement is also in line with research conducted by Ogah et al. ${ }^{19}$ and Reddy et al. ${ }^{21}$ This study was also comparable with research conducted by Punagi et al..$^{25}$ stating that interalar width in Bugis male are significantly wider than in Bugis female.

The average size of intercommissural width was significantly wider in females than males. Probably it is caused by the inhabitants of the district of Pammana no longer completely the descendants of the original ancestor Bugis, but blood mixing have already occurred because of the existing marriage. It is inversely proportional to the research conducted by Esan et al. ${ }^{2}$ stating that the commissural width in males is significantly wider than in females.

The result of this study also showed that measurement result of mesiodistal width of upper central incisor in males was significantly wider than in females. This is in line with a study conducted by Rieuwpassa et al. $^{10}$ and Reddy ${ }^{21}$ The study conducted by Sandhu et al. ${ }^{22}$ also compared with this study stated that the mesiodistal width of left or right upper central incisor in males is significantly wider than in females.

Further, this study defined a relationship between interalar width and intercommissural width against the mesiodistal width of upper central incisor in Buginese tribe in both sexes. Based on the results listed on table 3 that the relationship of the interalar width towards mesiodistal width of upper central incisors in Buginese tribe was weak with a positive direction, which means for each addition of interalar width there was also the addition of mesiodistal width of upper central incisor.

The tables also showed relationship of interalar width toward mesiodistal width of upper central incisor in male was not significant, which was also weak in the negative direction, which means each additional interalar width in male. Then there was also decrease of mesiodistal width of upper central incisors in male. It is inversely proportional to the research conducted by Qamar et al. ${ }^{9}$ stating that substantial relationship between interalar width and intercanine width is significant and weak with positive direction. The women showed the nasal base width relation to the mesiodistal width of upper central incisors were not significant, which was also weak in the positive direction, which means that for each addition of a base width of the nose there is also the addition ebar upper central incisor mesiodistal. It is comparable to the research conducted by Qamar et al. ${ }^{9}$ but with a negative direction.

The women showed wide base relations nose against mesiodistal width of upper central incisors were not significant, which was weak in a positive direction, which means that each additional base width of the nose occurs in women then there are also additional ebar upper mesiodistal central incisor. This compares to a study conducted by Qamar et al. ${ }^{9}$ but with a negative direction.

The result of this study also showed that relationship of intercommissural width toward mesiodistal width of upper central incisor on the Bugis was not significant, which was weak in a positive direction, which means for each addition of intercommissural width there is also the addition of mesiodistal width of upper central incisor 
on the Bugis. There was Insignificant relationship probably because this study used only one element, right or left upper central incisor, while according to the second theory intercanine angle was proportional to the intercommissural width which measured from the cheilion point on both corners of the mouth. Another possibility might be caused by differences in the results of this research is according to research conducted by Mahesh et al. ${ }^{17}$ where intercommissural width that correspond to the golden proportion to the intercommissural width when we smile. However, the study was conducted at the time when the mouth was in arelaxed state.

This study is inversely proportional to the research conducted by Sinavarat et al. ${ }^{20}$ stating that the relationship of intercommissural width toward mesiodistal width of upper central incisor in male was not significant and weak in negative direction, which means for every addition of intercommissural width then there is also decrease in mesiodistal width of upper central incisor in male. This is proportional to study that is conducted by Hussain et al. ${ }^{23}$ which stated intercommissural width toward intercanine width was not significant and weakin negative direction. The research conducted by Deogade et al. ${ }^{24}$ suggested that substantial relationship between intercommissural width against mesiodistal width of the maxillary anteriorteeth are not significant and weak in negative direction is also comparable to this study.

This study also showed that there is a significant relationship between interalar width and intercommissural width in Buginese tribe with positive direction, which means every addition of interalar width there was also the addition of intercommissural width in Buginese tribe. Table 5 also showed significant relationship between interalar width toward inter commissural width in male with a positive direction, which means for each addition of interalar width there was also the addition of intercommissural width in males.

From the results of this study we can project the proportion between interalar width, intercommissural width and mesiodistal width of upper central incisor in Buginese which is in male 5.49:6.79:1 and in female 5.50:7.12:1. The proportion of interalar width toward intercommissural width was 1:1:23 in male and 1:1:29 in female. This proportion does not correspond with the golden proportion that suggested the proportion of interalar width toward intercommissural width is $1: 1.618$. This study also found the proportion between mesiodistal width of upper central incisor toward interalar width which is 1:5.49 and the proportion between mesiodistal width of upper central incisor toward intercommissural width was 1:6.79 in male and the proportion between mesiodistal width of upper central incisor toward interalar width was 1:5:50 and the proportion between mesiodistal width of upper central incisors toward intercommissural width was 1:7:12 in female.

\section{Conclusion}

There is no significant relationship between interalar width and intercommissural width against mesiodistal width of upper central incisor in Buginese tribe.

Interalar width and intercommissural width was directly proportional to the mesiodistal width of upper central incisors in Buginese tribe. Interalar width and intercommissural width was inversely proportional to the mesiodistal width of upper central incisors in males and directly proportional in women.

\section{Conflict of Interest}

The authors report no conflict of interest.

\section{References}

1. Sharma S, Nagpal A, Verma. Correlation between facial measurements and the Mesiodistal width of the maxillary anterior teeth. Indian J Dent Sci 2012;4: 20.

2. Esan, Oziegbe, Onapokya. Facial approximation: evaluation of dental and facial proportions with height. Afr Health Sci 2012;12: 63.

3. Ali KA. Current concepts of selecting teeth for complete dentures among dentists in Riyadh, Saudi Arabia. Pak Oral Dental J 2009;29: 177-180.

4. Bali P, Singh S, Singh AP, et al. Biometric relationship between inner canthal distance and geometric progression for the prediction of maxillary central incisor width. Indian J Dental Sci 2013;5: 53.

5. Hossain S, Islam KZ, Islam M. Correlation between maxillary canines and facial anatomical landmarks in a group of Bangladeshi people. City Dental College J 2012;9: 12.

6. Punagi AQ, Julianita. Analisis fotometrik wajah suku-suku di Sulawesi Selatan dan Sulawesi Barat. Maj Kedokt Indo 2008;58: 370-376.

7. Irsa R, Syaifullah, Tjong DH. Variasi kefalometri pada beberapa suku di Sumatera Barat Cephalometry variation of ethnics in West Sumatra. Jurnal Biologi Universitas Andalas 2013;2: 130.

8. Mahdi E, Abolfazl N, Fariba K, et al. An investigation on cephalometric parameters in Iranian population. J Dev Biol Tissue Eng 2012;4: 9.

9. Qamar K, Hussain MW, Naeem S. The role of the interalar width in the anterior teeth selection. Pak Oral Dental J 2012;32: 570

10. Rieuwpassa IE, Hamrun N, Riksavianti F. Ukuran Mesiodistal dan Servikoinsisal Gigi Insisivus Sentralis suku Bugis, Makassar, dan Toraja tidak menunjukkan perbedaan yang bermakna. Dentofasial J 2013;12: 1-4.

11. Eboh. Nasal Indices among Bini Adolescents in Edo State Nigeria. Int J Morphol 2011;29: 1231-1234.

12. Dixon AD. Anatomy for student of dentistry (Buku Pintar Anatomi untuk Kedokteran Gigi) 5th ed. Jakarta: Hipokrates; 1993. p. 247. 
13. Anonim. Anatomi umum \& collifacialis. Makassar: Bagian Anatomi Fakultas Kedokteran Universitas Hasanuddin; 2012. p. 98-109.

14. Nelson SJ, Ash MM. Wheeler's Dental Anatomy, physiology, and occlusion. 9th ed. China: Elsevier; 2010. p. 13, 99-102,105.

15. Zarb GA. Boucher's Prosthodontic treatment for edentulous patients (Buku Ajar Prosthodonti untuk Pasien Tak Bergigi Menurut Boucher). Jakarta: EGC; 2002. p. 283, 287-289.

16. Bali P, Singh S, Singh AP, et al. Biometric relationship between inner canthal distance and geometric progression for the prediction of maxillary central incisor width. Indian J Dental Sci 2013;5: 54-55.

17. Mahesh, Rao S, Kumar P, et al. An in vivo clinical study of facial measurement for anterior teeth selection. Ann Essence Dent 2012;4: 1-6.

18. Ciortea C. Factori implicati in analiza esteticas Zonei Frontale Maxilare. Romanian J Stoma 2014;60: 35-40.

19. Ogah SA, Segun SB. Sexual dimorphism in nasal morphology as seen at the University of Ilorin teaching hospital, Ilorin, Nigeria. IOSR JDMS 2014;13: 45-48.

20. Sinavarat P, Anunmana C, Hossain S. The relationship of maxillary canines to the facial anatomical landmarks in a group of Thai people. J Adv Prosthodont 2013;5: 369-373.

21. Reddy N, Singh TR, Reddy S, et al. A cross-sectional clinical study on shape of nose inner-canthal distance and geometric progression as predictor for width of the maxillary incisor teeth. J Nat Sc Biol Med 2014;5: 265-267.

22. Sandhu N, Sandhu SS, Kaur B. Research: Role played by soft tissue landmarks Such as philtrum in selecting the width of artificial naxillary central incisors. Indian J Dental Sci 2012;4: 31-34.

23. Hussain MW, Qamar K, Naeem S. Significance of intercommissural width and anterior teeth selection. Pak Oral Dental J 2013;33: 393-396.

24. Deogade SC, Mantri SS, Saxena S, et al. Correlation between combined width of maxillary anterior teeth, interpupillary distance and intercommissural width in a group of Indian People 2014;4: 105-111.

25. Punagi AQ, Julianita. Analisis Fotometrik Wajah Sukusuku di Sulawesi Selatan dan Sulawesi Barat (Studi Antropometrik Sub Ras Deutero Melayu dan Proto Melayu) 2011;24: 26-33.

26. Cahyono F. Kombinatorial dalam Hukum Pewarisan Mendel. Makalah II2092 Probabilitasdan Statistik 2010.

27. Available from: URL: http//id.wikipedia.org/wiki/ Hukum_Pewarisan_Mendel. Accesed September 1, 2015.

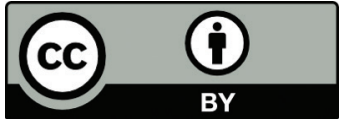

This work is licensed under a Creative Commons Attribution 